\title{
HEALTH POLICIES AND PRACTICE Can disease control priorities improve health systems performance in South Africa?
}

\author{
L C Rispel, P Barron
}

Improving health systems performance in order to achieve good health care outcomes and meet the Millennium Development Goals (MDGs) has received increased global attention. Using the World Health Organization (WHO)'s framework on health system strengthening, an overview is presented of key aspects of performance of the South African (SA) health system that are likely to impact on the Disease Control Priorities (DCP) initiative.

SA is gripped by a complex disease burden, consisting of the twin epidemics of HIV and tuberculosis, as well as non-communicable diseases and injuries. Despite an enabling legal and policy framework, health system challenges include sub-optimal leadership, insufficient resources for many national policies, lack of a broad public health approach to service delivery, and poor utilisation of existing information for decision-making.

Provided that these and other health systems issues are addressed, cost-effectiveness studies and interventions may be beneficial in improving the functioning of the health system in SA and in getting better value for money.

\section{Background}

In the past few decades, the combination of biomedical and technological advances, a substantial increase in global knowledge to improve population health, and improved access to primary health care, essential drugs, water and sanitation has resulted in aggregate worldwide improvements in the health of individuals and communities. ${ }^{1-2}$ However, this progress has been marred by a multiplicity of factors, including globalisation, changing burden and complexity of disease profiles, inequalities between and within

Laetitia Rispel is adjunct Professor in the Centre for Health Policy, School of Public Health, University of the Witwatersrand, Johannesburg, current President of the Public Health Association of South Africa (PHASA), and the principal investigator of a large research programme on Human Resources for Health (HRH). She was Executive Director of the Social Aspects of HIV/AIDS and Health Research Programme at the Human Sciences Research Council, and was head of the Gauteng provincial health department from 2001 until 2006.

Peter Barron is a medical doctor, public health specialist and previous accountant with more than 30 years of public health sector experience, both as a clinician and manager in local and provincial government. The main focus of his recent work has been around improving the quality of care at primary care level and implementation of a district health system in South Africa. He has published widely on immunisation, maternal and child health, district health, quality of care, health information systems and health service delivery. countries, and inadequate or poorly performing health systems. ${ }^{1}$ Common shortcomings of contemporary health systems include fragmented, unsafe and misdirected care, which mitigates against a comprehensive and balanced response to health needs.

Improving health systems performance to achieve good health care outcomes and meet the MDGs has received increased global attention, especially in the last decade. ${ }^{1,3-9}$ In SA, the current health political leadership has committed itself to a substantial overhaul of the public health sector in order to address the complex burden of disease; improve health outcomes, access and affordability; and ensure responsiveness to the needs of the population. ${ }^{10}$ The DCP project in SA aims to determine which effective interventions should be included in a package of care that offers the greatest gain in health (or averted disease burden) per SA rand spent. ${ }^{11}$ The DCP can contribute to health policy changes and improve and prioritise health resource allocation and spending provided that it takes account of the existing issues and challenges in the health system and pays attention to process and those stakeholders who have the potential to take forward, block or challenge policy change or implementation.

Using the WHO's framework on health systems strengthening, we present an overview of key aspects of performance of the SA health system that are likely to impact on DCP-SA. Critical issues are suggested that must be taken into account in the execution of DCP-SA.

\section{Measuring health systems performance}

The measurement of health systems performance is not straightforward, as health systems are complex, consisting of all organisations, people and actions whose primary intent is to promote, restore or maintain health. ${ }^{6-8}$ Measurement tends to focus on the provision of health services and is often hampered by data problems, the difficulty of defining measurable objectives in a reliable and valid manner, and the challenge of capturing social determinants of health and community experiences. ${ }^{12-13}$ The WHO health systems strengthening framework, despite critique of its limitations, is useful in focusing attention on the performance of the health system by linking system building blocks, performance elements and overall outcomes, including population health status. $^{8}$

An adaptation of the WHO framework is shown in Fig. $1^{8}$ and consists of the following:

Health system building blocks. These include six building blocks of service delivery; human resources (health workforce); finances; medical products, vaccines and technology; information; and leadership and governance.

Health delivery platforms include the district health system; hospitals; and the private sector (both for-profit and non-profit organisations).

Health system performance includes equitable access, coverage, quality and safety.

System outcomes include improved health (level and distribution); social and financial risk protection; responsiveness; and improved efficiency. 


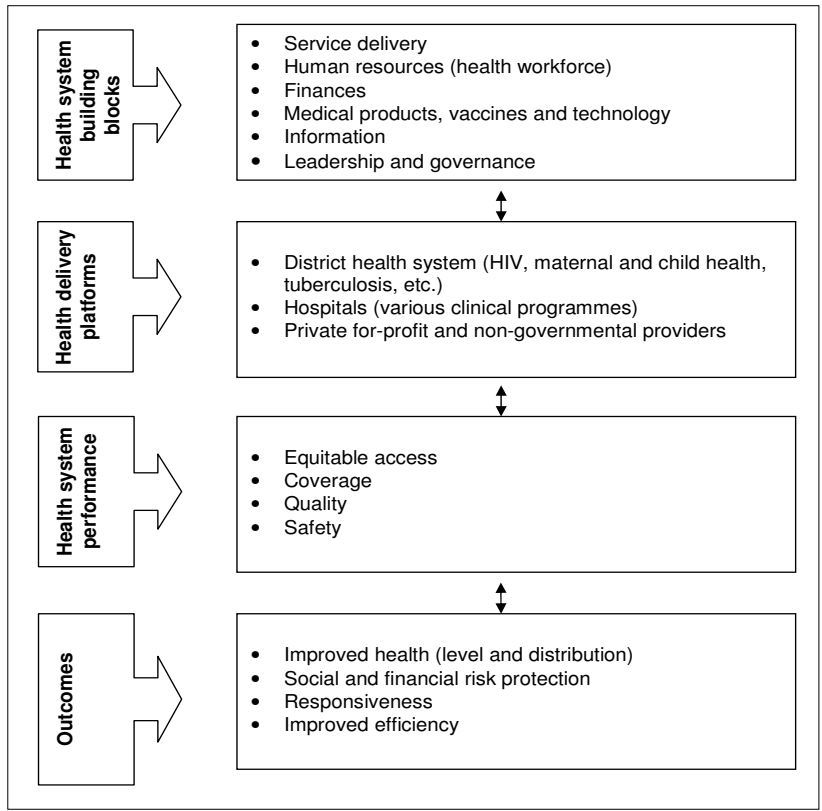

Fig. 1. World Health Organization health systems framework (source: redrawn and adapted from $\mathrm{WHO}, 2007){ }^{8}$

\section{Assessing the South African health system \\ System building blocks}

The democratic SA government inherited a highly fragmented health system in 1994, with wide disparities in health spending and inequitable distribution of health care professionals. There were inequities in access to and quality of care between and within provinces; between black and white; between urban and rural areas; and between the public and private health sectors. ${ }^{3,6,14-16}$ Transformation efforts in the health sector spanning more than 15 years include numerous structural, legislative and policy changes, overcoming apartheid in health services, implementation of health programmes for priority conditions, and improvements in access to health care services. ${ }^{6,17}$ There have been numerous positive developments and improvements in the lives of South Africans since the country's democratic transition. ${ }^{15,18-19}$ However, urban/rural and public/private inequities remain acute, and are exacerbated by numerous health system challenges. ${ }^{19-22}$

An enabling legal and policy framework is in place, and there have been many areas of progress (Table I). At the same time, significant health system challenges for each of the six health system building blocks need to be addressed. ${ }^{10,20,22}$

\section{Delivery platforms}

Resources are being inequitably and inefficiently used in the SA health system. Specific examples of primary care, district and central hospitals follow.

Table II shows the district primary health care spending trends. ${ }^{23}$ The districts are categorised from highest to the lowest spending per capita. Paradoxically, from an equity perspective, some of the largest percentage increases occur in districts that are already spending higher than the average per capita. ${ }^{23}$ The data highlight the marked differences in spending on primary health care.

Fig. 2 shows the cost of keeping an average patient in a district hospital for one day, the patient-day equivalent (PDE), an indicator showing on average how much it costs for one patient to spend one day in the hospital. This figure illustrates the wide differences between districts, which conceal the even greater differences between

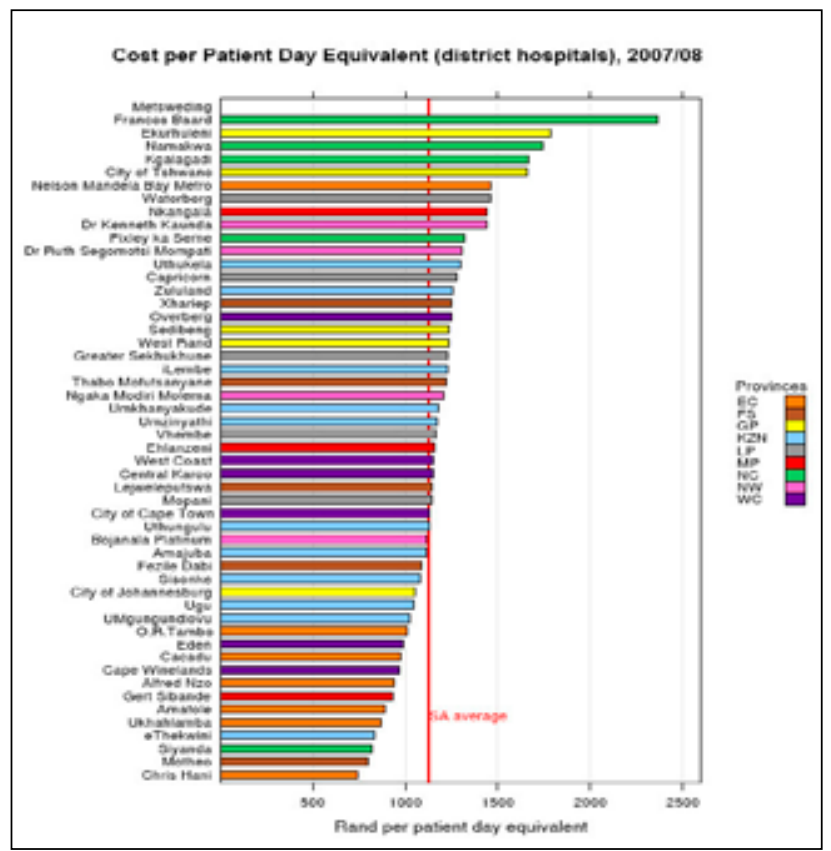

Fig. 2. Cost per patient-day equivalent at district hospitals, 2007/8 (source: Day et al., 2009 $9^{24}$ ).

individual hospitals. Even in the same province there is a wide range. For example, in the Eastern Cape the cost per PDE in Nelson Mandela Bay Metro is twice as high as in Chris Hani. ${ }^{24}$

As district hospitals consume over $40 \%$ of total district resources, the wide ranges in PDE are of great concern. Costs at the high end may indicate lack of efficiency or leakage out of the system, while costs at the low end may indicate poor quality of care.

Table III shows selected indicators in a sample of tertiary hospitals. ${ }^{22}$ Focusing on the cost per PDE indicates a wide range of potential inefficiencies in the system. Some central, academic hospitals in KwaZulu-Natal and the Free State are more expensive than those in the Western Cape and Gauteng, partly because the institutions are not working at optimal capacity. ${ }^{22}$

These differences point to poor monitoring and accountability at all levels of the system.

\section{How healthy are South Africans?}

Health outcomes in SA are poor and not commensurate with the level of health expenditure in the country. Scientists have described a quadruple burden of diseases in SA, comprising HIV and AIDS, poverty-related diseases, chronic diseases of lifestyle and high rates of injury. ${ }^{15,20,25}$

SA has an estimated 5.5 million people living with HIV, with an HIV prevalence of close to $30 \%$ of all public sector antenatal clinic attendees, and wide geographical differences. ${ }^{26}$ The rise of HIV prevalence has been followed relentlessly by a threefold increase in the incidence of tuberculosis (TB) from 1996 to 2006 (Fig. 3). ${ }^{27}$ Mortality statistics show an increase in deaths due to TB, from $13.1 \%$ of all deaths in 1997 to $25.5 \%$ in 2005 , and deaths due to pneumonia increased from $4.8 \%$ in 1997 to $8.7 \%$ in $2005 .{ }^{28}$ These large increases are almost certainly due to the classification of AIDS-related illnesses into these categories.

After HIV and AIDS deaths (29.8\%), cardiovascular disease (16.6\%), infectious and parasitic diseases (10.3\%), malignant neoplasms (7.5\%), intentional injuries (7.0\%) and unintentional injuries (5.4\%) were the leading cause of death in $2000 .{ }^{25}$ Hence, noncommunicable diseases (NCDs) and injuries constitute a growing 
Table I. Assessing health system building blocks in South Africa

\begin{tabular}{|c|c|c|}
\hline Building block & Elements of progress & Key issues/challenges \\
\hline Leadership and governance & $\begin{array}{l}\text { - Enabling legal, policy and } \\
\text { fiscal environment } \\
\text { - Existence of inter- } \\
\text { governmental health structures } \\
\text { - Visible political leadership in } \\
\text { fourth term of government } \\
\text { - Commitment to strengthen } \\
\text { public health sector } \\
\text { - Keenness and willingness to } \\
\text { correct past mistakes }\end{array}$ & $\begin{array}{l}\text { - Lack of a single national health vision and strategy for the } \\
\text { achievement of population health outcomes and ongoing health } \\
\text { system transformation } \\
\text { - Fragmentation between national, nine provincial and numerous } \\
\text { municipal health departments } \\
\text { - Resource allocation structurally disconnected from national } \\
\text { policies } \\
\text { - Loss of institutional and organisational health system focus, with } \\
\text { weak systems at all levels of the health sector } \\
\text { - Domination of disease-specific processes to the detriment of health } \\
\text { system functions } \\
\text { - Sub-optimal stewardship and leadership to ensure sufficient } \\
\text { resources for a range of national policies } \\
\text { - Hitherto antagonistic approach to dealing with key stakeholders } \\
\text { - Private sector inadequately regulated } \\
\text { - Difficult to attribute responsibility/accountability for performance }\end{array}$ \\
\hline Service delivery & $\begin{array}{l}\text { - Comprehensive and wide } \\
\text { range of services available } \\
\text { through the public sector } \\
\text { - Five year national strategic } \\
\text { plans to address HIV and } \\
\text { AIDS; TB } \\
\text { - Leader in a number of areas, } \\
\text { e.g. system of confidential } \\
\text { enquiry into maternal deaths, } \\
\text { antiretroviral treatment for } \\
\text { those in need of care, etc. }\end{array}$ & $\begin{array}{l}\text { - Lack of broader public health approach to service delivery } \\
\text { - National affordable, costed norms, standards and guidelines not } \\
\text { - Few synergies between key programme clusters, e.g. HIV, TB and } \\
\text { MCH managers, resulting in missed opportunities to improve } \\
\text { health outcomes at reduced costs } \\
\text { - Implementation sub-optimal and varies considerably across the } \\
\text { - Insufficient attention to quality at delivery levels } \\
\text { - Little recognition of the inter-connectedness of different } \\
\text { components of the health system, and links between high level } \\
\text { policies and implementation }\end{array}$ \\
\hline Human resources & $\begin{array}{l}\text { - Enabling legislation } \\
\text { - Overall national human } \\
\text { resource framework } \\
\text { - Strong health science training } \\
\text { faculties and generally good } \\
\text { training infrastructure } \\
\text { - Numerous efforts to improve } \\
\text { conditions of service of } \\
\text { health care professionals, } \\
\text { with occupation-specific } \\
\text { dispensations the latest policy } \\
\text { initiative }\end{array}$ & $\begin{array}{l}\text { - Poor co-ordination of health science education and training } \\
\text { between departments of Health and Education and higher } \\
\text { education institutions } \\
\text { - Inadequate production of health professionals in a number of key } \\
\text { categories } \\
\text { - Declining numbers and capacity of teaching faculty in major } \\
\text { disciplines } \\
\text { - Training perceived to be irrelevant to the requirements of the health } \\
\text { sector in terms of burden of disease (curriculum content) and the } \\
\text { district-based design of the health system (sites of training) } \\
\text { - Lack of alignment and integration of community health workers } \\
\text { and mid-level workers into the health system } \\
\text { - Less than optimal co-ordination and management of human } \\
\text { resources across the three spheres of government } \\
\text { - Huge inequities in the human resource availability between private } \\
\text { and public sectors; urban and rural areas } \\
\text { - Major leadership challenges at almost all levels of the health system, } \\
\text { exacerbated by weak personnel management systems } \\
\text { - High degree of centralisation, with HR delegations withdrawn in } \\
\text { most provinces } \\
\text { - Migration and high attrition of highly skilled professionals } \\
\text { Insufficient attention on impact of HIV and AIDS on the health } \\
\text { workforce }\end{array}$ \\
\hline
\end{tabular}


Table I. Assessing health system building blocks in South Africa (continued)

\begin{tabular}{|c|c|c|}
\hline Building block & Elements of progress & Key issues/challenges \\
\hline Finance & $\begin{array}{l}\text { - Enabling legislation } \\
\text { - } 8 \% \text { of gross domestic product } \\
\text { spent on health } \\
\text { - Public sector spending on } \\
\text { health has improved to almost } \\
14 \% \text { and fairly constant over } \\
\text { the period } 2004 \text { - } 2011 \sim \text { in } \\
\text { line with the call of the African } \\
\text { Union to spend } 15 \% \text { of total } \\
\text { budgets on health } \\
\text { - The ratios between the best } \\
\text { resourced province and the } \\
\text { worst resourced province } \\
\text { have decreased from } 3.8 \text { to } 1.6 \\
\text { between } 1995 / 96 \text { and } 2007 / 08 \\
\text { - Prioritisation of district health } \\
\text { services and emergency } \\
\text { medical services over } \\
\text { provincial and central hospital } \\
\text { services }\end{array}$ & $\begin{array}{l}\text { - Around } 55-60 \% \text { spent in the private sector, which covers less than } 20 \% \\
\text { of the population } \\
\text { - Relatively poor performance for the cost per capita inputs invested } \\
\text { - Lack of alignment between annual health budgets and strategic and } \\
\text { operational plans } \\
\text { - Determination and allocation of conditional grants not sufficiently } \\
\text { objective and quantifiable } \\
\text { - Numerous 'unfunded mandates' put significant pressures on the } \\
\text { allocated health budget } \\
\text { - Chronic overspending in the majority of provinces, the exact amount } \\
\text { significantly understated } \\
\text { - Costing of health sector activities and interventions is deficient } \\
\text { - Inadequate financial management, reporting and accountability } \\
\text { processes }\end{array}$ \\
\hline Medical technology, vaccines & $\begin{array}{l}\text { - Enabling legislation, aimed } \\
\text { to improve access to essential } \\
\text { medicines } \\
\text { - Essential drug lists } \\
\text { institutionalised } \\
\text { - Centralised procurement } \\
\text { system in public sector } \\
\text { - Single exit price for medicines }\end{array}$ & $\begin{array}{l}\text { - Insufficient prioritisation of pharmaceuticals } \\
\text { - Shortage of medicines, particularly in rural areas } \\
\text { - Sub-optimal supply chain processes including pro-active planning, } \\
\text { stock control and distribution processes } \\
\text { - Inadequate analysis, interpretation; and utilisation of information for } \\
\text { decision making } \\
\text { - Poor quality control of existing data collection } \\
\text { - Performance in relation to health priorities not quantified or } \\
\text { quantifiable }\end{array}$ \\
\hline Information & $\begin{array}{l}\text { District Health Information } \\
\text { System (DHIS) well- } \\
\text { established data collection } \\
\text { system, with great potential } \\
\text { as a comprehensive system of } \\
\text { routine data collection } \\
\text { - Significant time and resource } \\
\text { investment in data collection, } \\
\text { capture and collation }\end{array}$ & $\begin{array}{l}\text { - Insufficient linkages between health information, human resource and } \\
\text { financial information systems }\end{array}$ \\
\hline
\end{tabular}

public health problem, which must be addressed at the same time as HIV and TB. ${ }^{29}$

\section{Implications for DCP in South Africa}

This assessment paints a picture of a society that is gripped by a complex disease burden: the twin epidemics of HIV and TB, coupled with non-communicable diseases and injuries. The health system is inordinately complex. Visible and decisive leadership is needed to contextualise and prioritise the interventions required to improve the health system and the health status of South Africans. ${ }^{22}$

Although considerable resources are being spent on health and there have been massive improvements in reducing inequitable spending, there are still large disparities exemplified by the per capita expenditure on non-hospital primary health care. ${ }^{23-24}$

Data from district hospitals point to large-scale inefficiencies among individual hospitals and also among different provinces. Cost- effectiveness studies and interventions may improve the functioning of the health system in SA and get better value for money. However, key issues must be taken into account in any DCP initiative that is taken forward:

- The risk of emphasising selective interventions in health care delivery, inherent in the cost-effectiveness approach. Hence, any DCP project should take into account the complex disease burden and existing challenges in the health system, and aim to analyse the cost-effectiveness of integrated services.

- The technical complexity and enormous data inputs required for cost-effectiveness analyses. The project should ensure that due emphasis is placed both on building local capacity at universities, and on building capacity within government to utilise the information.

- The reality that budgeting and planning is not zero-based, i.e. future planning must take into account existing services and systems. Therefore the information gathered in the cost-effectiveness 
Table II. District primary health care spending per capita (rands), 2005/06 - 2007/08

\begin{tabular}{|c|c|c|c|c|c|}
\hline District & & $2005 / 06$ & $2006 / 07$ & $2007 / 08$ & $\begin{array}{c}\text { Annual } \\
\text { real } \\
\text { growth } \\
2005 / 06 \text { - } \\
2007 / 08\end{array}$ \\
\hline DC6 & Namakwa & 415 & 498 & 633 & 16.3 \\
\hline DC5 & Central Karoo & 294 & 321 & 526 & 26.1 \\
\hline DC1 & West Coast & 373 & 464 & 466 & 5.3 \\
\hline СРT & $\begin{array}{l}\text { City of Cape } \\
\text { Town }\end{array}$ & 354 & 384 & 445 & 5.6 \\
\hline DC4 & Eden & 325 & 347 & 435 & 9.0 \\
\hline DC43 & Sisonke & 239 & 273 & 416 & 24.3 \\
\hline DC38 & $\begin{array}{l}\text { Ngaka Modiri } \\
\text { Molema } \\
\text { (Central) }\end{array}$ & 280 & 328 & 398 & 12.2 \\
\hline DC16 & Xhariep & 331 & 361 & 387 & 1.9 \\
\hline DC7 & Pixley ka Seme & 236 & 294 & 376 & 18.9 \\
\hline JHB & $\begin{array}{l}\text { City of } \\
\text { Johannesburg }\end{array}$ & 288 & 313 & 371 & 7.1 \\
\hline DC39 & $\begin{array}{l}\text { Dr Ruth } \\
\text { Segomotsi } \\
\text { Mompati } \\
\text { (Bophirima) }\end{array}$ & 379 & 320 & 367 & -7.2 \\
\hline ETH & eThekwini & 282 & 305 & 365 & 7.2 \\
\hline DC45 & Kgalagadi & 253 & 277 & 353 & 11.3 \\
\hline DC2 & Cape Winelands & 272 & 291 & 353 & 7.4 \\
\hline DC40 & $\begin{array}{l}\text { Dr Kenneth } \\
\text { Kaunda } \\
\text { (Southern) }\end{array}$ & 292 & 311 & 342 & 2.1 \\
\hline DC27 & Umkhanyakude & 273 & 308 & 340 & 5.1 \\
\hline DC10 & Cacadu & 193 & 223 & 339 & 24.7 \\
\hline TSH & City of Tshwane & 245 & 311 & 335 & 10.3 \\
\hline DC3 & Overberg & 212 & 246 & 320 & 15.6 \\
\hline DC9 & Frances Baard & 202 & 261 & 314 & 17.6 \\
\hline DC29 & iLembe & 195 & 217 & 310 & 19.0 \\
\hline DC12 & Amathole & 251 & 265 & 305 & 3.9 \\
\hline DC13 & Chris Hani & 235 & 256 & 303 & 7.1 \\
\hline DC36 & Waterberg & 187 & 205 & 303 & 20.0 \\
\hline DC34 & Vhembe & 217 & 203 & 301 & 10.9 \\
\hline DC37 & $\begin{array}{l}\text { Bojanala } \\
\text { Platinum }\end{array}$ & 222 & 280 & 290 & 7.9 \\
\hline DC33 & Mopani & 218 & 235 & 290 & 8.7 \\
\hline DC46 & Metsweding & 198 & 150 & 287 & 13.4 \\
\hline DC26 & Zululand & 201 & 216 & 280 & 11.2 \\
\hline DC28 & Uthungulu & 227 & 229 & 278 & 4.2 \\
\hline DC23 & Uthukela & 171 & 195 & 277 & 19.7 \\
\hline DC22 & Umgungundlovu & 216 & 236 & 276 & 6.4 \\
\hline DC17 & Motheo & 254 & 296 & 274 & -2.1 \\
\hline EKU & Ekurhuleni & 243 & 286 & 273 & -0.2 \\
\hline
\end{tabular}

Table II. District primary health care spending per capita (rands), 2005/06 - 2007/08* (continued)

\begin{tabular}{|c|c|c|c|c|c|}
\hline District & & $2005 / 06$ & $2006 / 07$ & $2007 / 08$ & $\begin{array}{c}\text { Annual } \\
\text { real } \\
\text { growth } \\
2005 / 06 \text { - } \\
2007 / 08\end{array}$ \\
\hline DC21 & Ugu & 204 & 217 & 272 & 8.9 \\
\hline NMA & $\begin{array}{l}\text { Nelson Mandela } \\
\text { Bay Metro }\end{array}$ & 220 & 241 & 264 & 3.1 \\
\hline DC24 & Umzinyathi & 198 & 227 & 263 & 8.7 \\
\hline DC35 & Capricorn & 165 & 193 & 256 & 17.6 \\
\hline DC32 & Ehlanzeni & 164 & 187 & 256 & 17.8 \\
\hline DC14 & Ukhahlamba & 186 & 209 & 239 & 6.6 \\
\hline DC48 & West Rand & 242 & 221 & 236 & -6.9 \\
\hline DC42 & Sedibeng & 188 & 196 & 233 & 4.9 \\
\hline DC20 & Fezile Dabi & 228 & 222 & 230 & -5.3 \\
\hline DC31 & Nkangala & 160 & 195 & 226 & 12.1 \\
\hline DC15 & O.R. Tambo & 188 & 199 & 223 & 2.4 \\
\hline DC47 & $\begin{array}{l}\text { Greater } \\
\text { Sekhukhune }\end{array}$ & 121 & 163 & 221 & 27.2 \\
\hline DC25 & Amajuba & 151 & 177 & 220 & 13.6 \\
\hline DC30 & Gert Sibande & 137 & 185 & 211 & 16.9 \\
\hline DC19 & $\begin{array}{l}\text { Thabo } \\
\text { Mofutsanyane }\end{array}$ & 206 & 213 & 211 & -4.6 \\
\hline DC8 & Siyanda & 119 & 150 & 206 & 23.8 \\
\hline DC44 & Alfred Nzo & 177 & 202 & 198 & -0.5 \\
\hline DC18 & Lejweleputswa & 187 & 190 & 191 & -4.7 \\
\hline & Total & 232 & 256 & 302 & 7.6 \\
\hline \multicolumn{6}{|c|}{$\begin{array}{l}\text { * Ranked from highest to lowest per capita spending in } 2007 / 08 \text {. Includes five core sub-pro- } \\
\text { grammes and local government, but excludes health facilities management, PHC training, HIV } \\
\text { and AIDS and district hospitals sub-programmes. } \\
\text { Source: Bletcher et al. } 200{ }^{23}\end{array}$} \\
\hline
\end{tabular}

exercise must reflect the costs of adjusting the supply of a particular intervention upwards or downwards from its current level.

- The DCP should assist with the development of appropriate staffing models.

- The DCP should assist with discontinuation of health care interventions/activities that add no value to health outcomes.

- The DCP must recognise that society often places a disproportionate value on certain sorts of treatment, including expensive life-saving care. The approach should take into account public values and professional opinion and pay due attention to the context and processes of decision-making.

- Few developing countries have a comprehensive monitoring and evaluation system, existing systems suffer from lack of co-ordination and are often paper-based, and information generated has problems of quality, completeness, timeliness and duplication. The DCP should facilitate the development of a streamlined system, rather than exacerbate existing data requirements

- Lastly, the DCP should recognise that a technical approach to health sector priorities based on burden of disease and cost-effectiveness analysis should not be a rigid prescription for all health system ailments, but is only one input to the policy process. ${ }^{4}$ 
Table III. Bed utilisation rate and cost per patient-day equivalent in selected tertiary hospitals

\begin{tabular}{|c|c|c|c|c|c|c|c|}
\hline \multirow[t]{2}{*}{ Province } & \multirow[t]{2}{*}{ Hospitals } & \multicolumn{2}{|c|}{$2005 / 06$} & \multicolumn{2}{|c|}{$2006 / 07$} & \multicolumn{2}{|c|}{$2007 / 08$} \\
\hline & & BUR (\%) & PDE cost $(\mathrm{R})$ & BUR (\%) & PDE cost $(\mathrm{R})$ & BUR (\%) & PDE cost $(\mathrm{R})$ \\
\hline \multirow[t]{2}{*}{ Eastern Cape } & Nelson Mandela & 81 & $\mathrm{n} / \mathrm{a}$ & 76 & $\mathrm{n} / \mathrm{a}$ & 69 & $\mathrm{n} / \mathrm{a}$ \\
\hline & Port Elizabeth Provincial Hospital & 60 & $\mathrm{n} / \mathrm{a}$ & 69 & $\mathrm{n} / \mathrm{a}$ & 68 & $\mathrm{n} / \mathrm{a}$ \\
\hline Free State & Universitas & 61 & $\mathrm{n} / \mathrm{a}$ & 68 & 2735 & 71 & 3089 \\
\hline \multirow[t]{3}{*}{ Gauteng } & Chris Hani Baragwanath & 85 & $\mathrm{n} / \mathrm{a}$ & 74 & 1577 & 75 & 1843 \\
\hline & Charlotte Maxeke Johannesburg Academic & 86 & $\mathrm{n} / \mathrm{a}$ & 85 & 2043 & 81 & 2366 \\
\hline & Steve Biko Academic (Pretoria) & 77 & & 76 & 2206 & 74 & 2100 \\
\hline \multirow[t]{2}{*}{ KwaZulu-Natal } & Grey's Hospital & 67 & & 73 & 1585 & 74 & 2107 \\
\hline & Inkosi Albert Luthuli Central Hospital & 42 & $\mathrm{n} / \mathrm{a}$ & 46 & 4259 & 41 & 5299 \\
\hline Limpopo & Pietersburg Hospital (Polokwane) & 71 & $\mathrm{n} / \mathrm{a}$ & 75 & 1545 & 64 & 2147 \\
\hline Mpumalanga & Witbank & 71 & $\mathrm{n} / \mathrm{a}$ & 70 & 1857 & 69 & 2094 \\
\hline \multirow[t]{3}{*}{ Western Cape } & Groote Schuur & 83 & $\mathrm{n} / \mathrm{a}$ & 82 & 2195 & 81 & 2513 \\
\hline & Red Cross Children's War Memorial & 81 & $\mathrm{n} / \mathrm{a}$ & 84 & 2137 & 81 & 2487 \\
\hline & Tygerberg & 80 & $\mathrm{n} / \mathrm{a}$ & 81 & 2102 & 79 & 2395 \\
\hline
\end{tabular}

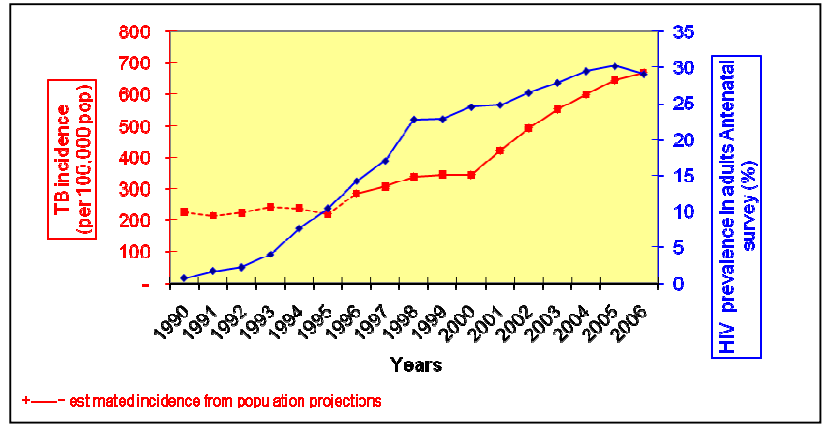

Fig. 3. Trend of incidence of tuberculosis and HIV prevalence (source: Department of Health, 2008 ${ }^{27}$.

We would like to thank Professors Karen Hofman and Steve Tollman for their encouragement and support. This paper is based on a longer report entitled: 'Overview of health care and the health system in South Africa: Implications for the Disease Control Priorities (DCP) project', done as part of the launch of the Priority Cost Effective Lessons for Systems Strengthening (PRICELESS) South Africa initiative, August 2009. The report was funded by the Fogarty International Center at the US National Institutes of Health and the Bill and Melinda Gates Foundation.

1. World Health Organization. The World Health Report 2008: Primary Health Care, Now More Than Ever. Geneva: WHO, 2008

2. Beaglehole R, Bonita R. Global public health: a score card. Lancet 2008:372:1988-1996.

3. Barron P, Roma-Reardon J, eds. South African Health Review 2008. Durban: Health Systems Trust, 2008. Rona-Res.

Murray CJ, Kreuser J, Whang W. Cost-effectiveness analysis and policy choices: investing in health systems. Bull World Health Organ 1994:72:663-674.

5. Rispel L, Setswe G. Stewardship: Protecting the public's health. In: Harrison S, Bhana R, Ntuli A, eds. South African Health Review 2007. Durban: Health Systems Trust, 2007.

6. Schneider H, Barron P, Fonn S. The promise and practice of transformation in South Africa's health system. In: Buhlungu S, Daniel J, Southall R, Lutchman J, eds. State of the Nation: South Africa 2007. Cape Town: Human Sciences Research Council, 2007.
World Health Organization. World Health Report 2000: Health Systems: Improving Performance. Geneva: World Health Organization, 2000

8. World Health Organization. Everybody's Business. Strengthening Health Systems to Improve Health Outcomes: WHO's Framework for Action. Geneva: World Health Organization, 2007.

9. Travis P, Bennett S, Haines A, et al. Overcoming health system constraints to achieve the Millenium Development Goals. Lancet 2004;364:900-906.

10. Department of Health. National Department of Health Strategic Plan 2010/11-2012/13. Pretoria: Department of Health, 2010.

11. Hoffman K. Scope and expectations of the South Africa Country Study. Paper presented at the launch workshop entitled 'Setting priorities for health: Crafting a South Africa-specific strategy', 10 - 12 August 2009, Mount Grace Country Hotel, Magaliesberg.

12. Loeb JM. The current state of performance measurement in health care. Int J Qual Health Care 2004;15:i5-i9

13. Navarro V. The new conventional wisdom: An evaluation of the WHO report Health systems: Improving performance. Int $J$ Health Serv 2001;31:23-33.

14. Chopra M, Lawn JE, Sanders D, et al. Achieving the health Millennium Development Goals for South Africa: challenges and priorities. Lancet 2009;374:1023-1031.

15. Coovadia H, Jewkes R, Barron P, Sanders D, McIntyre D. The health and health system of South Africa: historical roots of current public health. Lancet 2009;374:817-834.

16. Shisana O, Rehle T, Louw J, Zungu-Dirwayi M, Dana P, Rispel L. Public perceptions on national health insurance: Moving towards universal health coverage in South Africa. S Afr Med J 2006;96:814-818.

7. Health Systems Trust. South African Health Reviews. Durban: HST, 1995-2008.

18. Buhlungu S, Daniel J, Southall R, Lutchman J, eds. State of the Nation: South Africa 2007. Cape Town: Human Sciences Research Council, 2007.

19. Statistics South Africa. Achieving a Better Life for All: Progress between Census 1996 and 2001. Statistics South Africa. Achieving a

20. Development Bank of South Africa. Health Sector Roadmap. Johannesburg: DBSA, 2008

20. Development Bank of South Africa. Health Sector Roadmap. Johannesburg: DBSA, 2008.
21. Gilson L, McIntyre D. South Africa: The legacy of apartheid. In: Evans T, Whitehead M, Diderichsen F, Gilson L, McIntyre D. South Africa: The legacy of apartheid. In: Evans T, Whitehead M, Diderichsen F,
Bhuiya A, Wirth M, eds. Challenging Inequities in Health: From Ethics to Action. New York: Oxford University Press, 2001

22. Integrated Support Teams. Review of Health Over-spending and Macro-assessment of the Public Health System in South Africa: Consolidated Report. Pretoria: ISTs, 2009.

23. Bletcher M, Day C, Dove S, Cairns R. Primary health care financing in the public sector. In: Barron P, Roma-Reardon J, eds. South African Health Review 2008. Durban: Health Systems Trust, 2008.

24. Day C, Barron B, Montecelli F, Sello E, eds. District Health Barometer 2007/8. Durban: Health Systems Trust, 2009.

25. Bradshaw D, Nannan N, Groenewald P, et al. Provincial mortality in South Africa 2000 - priority setting for now and a benchmark for the future. S Afr Med J 2005;95:496-503.

26. Department of Health. National HIV and Syphilis Antenatal Prevalence Survey, South Africa 2008. Pretoria: Department of Health, 2009.

27. Department of Health. Tuberculosis Strategic Plan for South Africa, 2007-2011. Pretoria: Department of Health, 2008.

28. Statistics South Africa Mortality and Causes of Death in South Africa, 2003-2004. Pretoria. Statistics South Africa, 2006

29. World Health Organization. 2008-2013 Action Plan for the Global Strategy for the Prevention and Control of Non-communicable Diseases. Geneva: World Health Organization, 2008. 